\title{
La ética y estética del Advertimiento en la obra de Quevedo
}

\author{
Hernán SÁNCHEZ MARTÍNEZ DE PINILLOS \\ University of Maryland, at College Park \\ hsmdp@umd.edu
}

\section{RESUMEN}

Se describe la obra de Quevedo como una serie de variaciones sobre un antagonismo antropológico y ético: los modos del vivir advertido y divertido. Autor de ingeniosa prosa festiva y de cientos de poemas satírico-burlescos, Quevedo realizó paradójicamente en su obra grave una crítica moral y metafísica de la diversión. Asimismo, poetizó el concepto de diversión (con anterioridad al concepto de divertissement de Pascal) dentro de una prolongada meditatio mortis. A esta luz se sitúa la filosofía y poesía del advertimiento de Quevedo en el corazón de la tradición occidental, en una trayectoria que se extiende de Sócrates, los Evangelios, Séneca, San Agustín y Vives hasta Gracián, Pascal, Nietzsche y Ortega y Gasset.

Palabras clave: Quevedo, filosofía moral, ética, Pascal.

\begin{abstract}
Quevedo's literary works display a set of variations on the anthropological and ethical dichotomy between existential awareness ("el vivir advertido") and existential unawareness and aloofness ("la vida divertida"). As the author of hundreds of satirical and burlesque poems, Quevedo paradoxically exercised a sustained critique of the concept of "diversión". This essay examines the different ways Quevedo gives lyrical expression to the notion of "diversion" (Pascal's "divertissement") in a life-long meditatio mortis.

Quevedo's philosophy and poetry of moral awareness, while rooted in the leading currents of Western tradition (from Socrates, the Gospels, Seneca, Saint Augustine to Luis Vives), anticipates some of the main assumptions in the philosophy of Gracián, Pascal, Nietzsche, and Ortega y Gasset.
\end{abstract}

Keywords: Quevedo, Philosophy, Ethics, Pascal.

Quevedo, en la tradición retórica de las Epístolas familiares de Fray Antonio de Guevara, describió la condición humana dentro de un sistema de oposiciones explícitas: vida y muerte, salud y enfermedad, apariencia y realidad, riqueza y pobreza, ascenso y caída, paz y guerra, la naturaleza y la Gracia. La doctrina moral estoico-cristiana de Quevedo no surge en forma dialógica, sino encerrada dentro de una retórica "de espíritu geométrico", detenida en dualidades metafísicas y morales. Pero por otra parte en la obra imaginativa de Quevedo se 
confrontan a menudo fe dogmática y espíritu crítico, ascetismo moral y misticismo erótico, escatología y metafísica. En su escritura más audaz Quevedo desordenó y perturbó las creencias sociales más firmes por medio de contrasituaciones líricas y narrativas: en El Buscón el Carnaval y la Eucaristía convergían degradados en un ayuntamiento caníbal en la cena de Alonso Ramplón; las sacralizaciones del impulso erótico singularizan la poesía amorosa; las confluencias entre el mundo "por de fuera" y el mundo "por de dentro" provocan muchos pasajes irreverentes en Los sueños, etc. En el fondo, según trataremos de mostrar aquí, tras este mundo ideológico bipolar, o desordenado y subversivo, late una dicotomía antropológica, las llamadas por Quevedo formas de vida advertida y divertida. ${ }^{1}$

Resulta paradójico pero la obra del mayor prosista y poeta festivo del Siglo de Oro, autor de cientos de divertidísimos poemas satírico-burlescos, puede ser leída como una crítica constante de la diversión, término y concepto nuevos en el siglo XVII. Los diccionarios recogen estado divertido, tras "divertir", desde 1525, como equivalente de estado "ocioso", "distraído" o "apartado", pero también con San Agustín en un sentido teológico moral ${ }^{2}$, apartado del camino que conduce a la salvación, y en convergencia con el sentido moderno de "entretenimiento". Quevedo hermana pues la diversión a los "deleites" condenados por la patrística y los moralistas cristianos, hasta por ejemplo un Bernat Metge en Lo Somni ${ }^{3}$, y en esa tradición conmina a vivir tres formas (vinculadas) de vida: la religiosa, la vida advertida enderezada al bien moral, y la del humanista capaz de leer, o conversar con los difuntos mejores.

Afín a la antítesis barroca entre engaño y desengaño, entre sueño y despertar, la disyuntiva entre advertimiento y diversión es bíblica (locura contra la sabiduría o temor de Dios), platónica (la teoría del doble mundo) y escolástica (vita contemplativa frente a vita activa). Las relaciones entre la obra en prosa, y la poesía religiosa, amorosa y moral de Quevedo en torno a esta encrucijada de diversión y advertimiento revelan la coherencia de su mundo ideológico y poético: el joven distraído por los placeres y deleites del sueño en El mundo por de dentro es un allegado del penitente del Heráclito Cristiano y de la poesía moral; el diablo del sueño del Alguacil endemoniado o el anciano venerable del mismo "Mundo

\footnotetext{
${ }^{1}$ Por ejemplo, en la fantasía moral La hora de Todos y la Fortuna con seso se oponen el tiempo de la Fortuna y el tiempo de la verdad revelada; el "mundo al revés" -mundo terrenal caído en manos de la Fortuna, mundo de la diversión- y los desenmascaramientos sorpresivos por "la hora", agente de Júpiter y del advertimiento.

2 San Agustín, tan frecuentado por Quevedo, estructuró, sobre la raíz del latín vertere, "girar, hacer girar, dar vuelta, cambiar", la vida religiosa como etimología retórica metafísica donde las metáforas de movimiento, reversio, aversio, perversio y diversio, se resuelven en una conversio y conversatio con Dios.
}

${ }^{3}$ B. Metge (1985), p. 43. 
por de dentro" dilatan la conciencia moral arrepentida de los salmos penitenciales del Heráclíto Cristiano; el hombre caído de la poesía religiosa se prolonga en el hombre divertido de la poesía moral, extraviado en lo hondo de la cueva platónica, olvidado de su alma y de su condición mortal. Sentido moral y amoroso se funden en una dialéctica de contrarios en la oposición entre divertimiento y advertimiento, y en sus correlatos "fuego" y "desengaño", en el seno de la poesía amorosa; los hablantes de la poesía moral y amorosa no se abandonan al sueño físico o mental, insomnes penitentes o amantes que velan sin fin en la noche ${ }^{4}$. En suma el infierno de la escatología católica se vuelve interioridad desde donde hablan los atormentados personajes de las diversas musas. El hombre deshabitado de los poemas morales y amorosos es el hombre dormido ( Yo, dormido, en mis daños persevero» ${ }^{5}$ ) de la poesía religiosa; y frente a él sólo el hombre despertado y advertido, el hombre interior paulino, logra la «buena muerte», reservada a quien, tras Séneca, sabe que «vivimos muriendo». Y dentro de las correspondencias entre el vocabulario religioso y el moral en la obra de Quevedo, el advertimiento es expresión intelectual de la contrición y la atrición religiosas. El talante divertido representa, asimismo, una variación del "no-vivir dormido" de la poesía religiosa, así como de la «dureza de corazón» del hombre caído, impenitente, de corazón más duro e insensible que las piedras quebrantadas por el sufrimiento del Redentor ${ }^{6}$. En palabras del beato Tomás de Kempis en su Imitación de Cristo (1418): «Por eso vive siempre aparejado y con tanta vigilancia, que nunca la muerte te halle desapercibido, porque vendrá el Hijo de la Virgen en la hora que no se piensa» ${ }^{7}$. Al ser creación divina, el buen empleo moral del tiempo creado se vuelve en el Heráclito cristiano, bajo la metáfora casa/ladrón de Mateo 24:43, esencialmente dramático. El tiempo es forma del conocimiento (muerte) y del carácter (la vida advertida), pero ya no se trata sólo de hacer un uso sabio del tiempo terrenal, como en Séneca. Cuando Quevedo contrapone las actitudes

4 Véase: H. Sánchez M. de Pinillos (2005), p.183-213.

${ }^{5}$ Poema número 27, verso 5, en F. de Quevedo (1990). Las citas de la poesía de Quevedo son (salvo indicación en contrario) de esta edición, de J. M Blecua, Se indica el poema con su numeración en la edición de Blecua entre paréntesis.

${ }^{6}$ Véase: F. de Quevedo (1990); 152, 153, 154, 186.

${ }^{7}$ Imitación de Cristo, Primer Tratado, cap. 23 (1989), p. 76. También, entre múltiples citas posibles: «Mira que estés sobre aviso, y vela en oración, y humíllate en todas las cosas», Imitación de Cristo, cap. 28, p. 202. Son ajustados en lo doctrinal -no necesariamente en la práctica poética - las siguientes palabras: "Quevedo no se ha formulado el problema de la realidad objetiva del mundo. No le preocupa si la vida es sueño o no, ni si el mundo es mera representación. Este problema, de la mayor trascendencia filosófica, no le ha preocupado... no es Quevedo escéptico» a la manera de Lucrecio o Montaigne. F. Ynduráin (1969), pp. 171-214: 182-183. 
divertido/advertido ante el transcurrir de las horas, aunque originaria de Séneca, la oposición se llena, bajo la metáfora casa/ladrón en Mateo 24:43, de patetismo teológico cristiano. Bajo el signo del arrepentimiento el penitente del Heráclito Cristiano, de la poesía religiosa y de muchos poemas morales, se enfrenta al tiempo de la diversión desde una conciencia de tiempo escatológico. Como el diablo que predica en el Alguacil endemoniado ${ }^{8}$, el hombre advertido ordena conocer al tiempo ${ }^{9}$ en su dimensión moral; el hombre divertido, prisionero en la caverna platónica, existe en cambio, escapando de sí y disolviéndose en un presente sin consciencia, sumido en «el sueño de la muerte», entregado al espejismo de una falsa vida.

\section{Ocio y hombre interior}

La vida de contemplación filosófica fue celebrada como el bien mayor por Séneca en De otium y, con sentido religioso humanístico, por Petrarca en De vita solitaria (1346-1366) y De otio religioso (1357). En el otium el hombre puede «hacerse mejor» y elegir para sí propio un ideal humano conforme al cual modelar su vida; al apartarse de los negocios «puede (hacer) avanzar en una marcha equilibrada y en una misma dirección esa vida que nosotros desgarramos con proyectos contradictorios» ${ }^{10}$. Mientras el ocio del necio degenera en ociosidad, mera diversión, en cambio el ocio del hombre advertido es vigilia y meditación constantes sobre los límites del hombre ante la muerte. El advertimiento de la poesía moral y metafísica implica además un velar de la fe en el sentido escatológico del Evangelio (San Marcos 13:33, I Tesalonicenses 5:2, San Lucas 21:34, San Mateo 24:23) y de la poesía religiosa de Quevedo, pero es también llamada a permanecer despierto y mantenerse vigilante y alerta en un sentido intelectual. La poesía del amor insomne y de la imaginación nocturna, tiene su contrapartida en esta poesía moral de la consciencia cercada, como se lee en el Salmo XVI del Heráclto Cristiano por "el negro cerco" de la muerte ${ }^{11}$, y donde el ocio clásico -el otium cum dignitate de Cicerón en De Oratore (I, 1-2)- se transforma en velar doloroso como nueva epistemología (aquí existe concomitancia con el existencialismo donde la angustia tiene valor epistemológico y liberador).

Josef Pieper, filósofo católico y tomista, pensaba que la ética protestante de la redención por el trabajo se ha infiltrado en la civilización occidental hasta un

\footnotetext{
${ }^{8}$ F. de Quevedo (1993), p. 182.

${ }^{9}$ F. de Quevedo (1992), p. 1135.

10 «...tunc potest vita aequali et uno tenore procedere, quam propositis diversissimis scindimus», Seneca (1979), p. 180.

${ }^{11}$ Francisco de Quevedo (1990), num. 28, p. 27. Ver: H. Sánchez M. De Pinillos (1993)
} 
grado debilitante ${ }^{12}$, conduciendo al hombre moderno a arriesgarse a perder el alma, en sentido cultural y espiritual. Contra esta disposición vital intramundana, Pieper formula una apología católica y heideggeriana (incorporando las nociones de Gelassenheit y Aletheia) de la vida contemplativa y del ocio. Del ocio, no como se entiende en el siglo XXI, sino dentro de una teología de lo sagrado, y vinculada, tras Platón y Santo Tomás, al asombro, raíz de la filosofía y de la poesía. La importancia del ocio no fue cuestionada hasta que Kant usurpó en 1796 su lugar con su filosofía de la razón y del trabajo, preludio de la revolución industrial. Contra el pragmatismo moderno Pieper, partiendo del mandato del Salmo 46, vs 11: «Cesad, y reconoced que soy Dios», defiende el valor del ocio como un estado de plenitud y de calma receptiva y contemplativa idóneo para la experiencia de la gracia. En el contexto de la obra de Quevedo el tradicional elogio humanista del estudio y de la lectio secular es inseparable de un sentido moral: así en el soneto "Retirado en la paz de estos desiertos" el retiro estudioso significa apartamiento de la diversión y superación de la acedía - considerada por Santo Tomás de Aquino como una ofensa contra el mandamiento que ordena buscar la paz mental en Dios.

En su diálogo «Princeps puer», Juan Luis Vives presentaba a Moróbulo como un necio "divertido" para quien la vida consiste en evasión y juego, y por ello propone al infante Felipe fiestas y amores, naipes y danzas. Sofóbulo, en cambio, rechazaba y despreciaba la pereza, el ocio, los placeres y bromas, y aconsejaba a Felipe aplicarse con toda intensidad "al estudio y cultura del alma»" ${ }^{13}$. Bajo el signo del humanismo, Vives -como después Fray Luis, Montaigne, Cervantes ( $D Q$ I, Prólogo; II, 23) y el propio Quevedo- entendió el estudio lejos de la figura del erudito pedante, como cultura del alma y actividad vital, forma suprema del advertimiento y reverso de la experiencia del hombre deshabitado a quien "nadie responde" $"$. Según Vives, al estudioso le es posible siempre que lo desee "hablar con los muertos": Platón, Aristóteles, Cicerón, Séneca, Tito Livio, Plutarco "hablarán con vos todas las veces y todo el tiempo que os viniere en talento"15.

Sólo la lectura y el estudio triunfan para Quevedo sobre la dicotomía entre divertimiento y advertimiento, permitiendo al hombre adentrarse ociosamente en la verdad, en un ocio interior - «Oisiveté, mais pleine de pouvoir» ${ }^{16}$ - opuesto al ocio cronométrico. En el Sueño de la muerte el narrador se quedaba dormido, en tanto que su alma "se vio ociosa, sin la tarea de los sentidos exteriores" 17 , y por

12 J. Pieper (1952). Véase también: Pedro Laín Entralgo, El ocio y el trabajo, 1960.

${ }^{13}$ J. L. Vives (1948), pp. 946-951: 951.

${ }^{14}$ H. Sánchez M. De Pinillos (1997).

15 J. L. Vives (1947), p. 949.

${ }^{16}$ P. Valery (1971; orig. 1920), p. 14.

${ }^{17}$ F. de Quevedo (1993), p. 318. 
tanto libre para recibir las comunicaciones, "más bien inconscientes"18 de las potencias de alma, memoria, entendimiento y voluntad. Asimismo, en la lectura retirada en comunión con "las grandes almas ausentes" del soneto "Retirado en la paz de estos desiertos", en ausencia de lo accesorio, de preocupaciones materiales, en el silencio creador de espíritu y de bondad, el hombre puede liberarse de la sombra del tiempo divertido, manchado por el pecado original. La conversación con los difuntos del humanista es un hablar con y contra la muerte. Sin el saber de «las grandes almas», la política, la amistad, el amor y la guerra serían vanas diversiones, juegos de niños. En la soledad sonora, habitada, compartida, del estudio -como espacio vital y como actividad -germina un hombre nuevo quien, en comunión con los muertos, participa de la invención creadora de la persona latente, y trasciende así al hombre dormido, deshabitado, divertido.

\section{Hombre divertido, hombre deshabitado}

En la prosa y la poesía satíricas, los sujetos «divertidos» son víctimas del ingenio lúdico de Quevedo, y de la perspectiva autorial advertida, que observa el mundo como realidad, por de dentro. Poseídos por una vanidosa inconsciencia (juegos, apariencias, placeres), los personajes divertidos (cornudos, pretendientes cortesanos, lindos, calvos rebeldes, viejos teñidos, valentones, alcahuetes, franceses vanos, italianos sodomitas, etc.) devienen, mirados desde el desengaño y el advertimiento, figuras grotescas. Por otra parte, Polimnia y Urania -es decir, respectivamente, la poesía moral y la poesía sacra-, y en primera persona $U n$ Heráclito Cristiano confrontan dos disposiciones vitales irreductibles: la «que se pasa en contentos y locura» ${ }^{19}$, y la del tormento (presente, insomne) lúcido de la consciencia moral que conoce, en lugar de llorar, «las advertencias que la edad te envía ${ }^{20}$. Asimismo los poemas morales metafísicos se articulan sobre el conflicto irresuelto entre el anhelo de alcanzar un paraíso de inconsciencia divertida (juegos, placeres) y el deber de vivir con integridad moral de cara a la realidad de la muerte; por no ser capaces de resolver el conflicto "Los sin ventura muertos de repente" dan en la condena eterna en el Sueño del infierno: "Mentís -dijo un diablo-, que ningún hombre muere de repente; descuidado y divertido, sí” ${ }^{21}$. Los poemas morales y de Un Heráclito cristiano presentan a un sujeto que se debate entre olvido de sí y abandono mundano y el despertar a una conciencia advertida, condición del autodominio del hombre digno de sí.

Por otra parte, la tonalidad en los poemas morales que don José Manuel Blecua clasificó como "metafísicos" no es estoica. Si en la teoría moral el advertimiento implica vivir serenamente frente a la muerte, en la práctica poética el miedo y la

\footnotetext{
${ }^{18}$ F. de Quevedo (1993), p. 73.

${ }^{19}$ F. de Quevedo (1990), 1, v. 13.

${ }^{20}$ F. de Quevedo (1990), 1, v. 13.

${ }^{21}$ F. de Quevedo (1993), p. 225.
} 
ansiedad de la última hora, la experiencia del despertar intelectual a la muerte, y una transición dolorosamente dramática del ser divertido al advertimiento estructuran los poemas morales más subjetivos ("Señor don Juan, pues con la

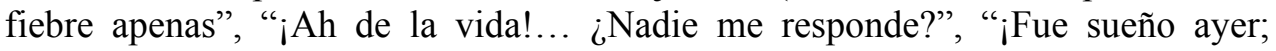
mañana será tierra!", "Si no temo perder lo que poseo", "Huye sin percibirse, lento, el día", etc). Tras la dicotomía entre el anciano advertido y el joven ingenuo del sueño El mundo por de dentro ${ }^{22}$, Quevedo logra fundir en la voz lírica de estos poemas "metafísicos" las perspectivas y vivencias del deseante divertido y la del hombre maduro a quien le sobreviene repentinamente el desengaño. La despreocupación del hombre divertido, ciego al paso de las horas que le consumen, es consciencia del «cerco», angustia de saberse sitiado por tiempo y cielo que, en la concepción de Ptolomeo, giran en torno a la tierra y deshacen al hombre. La imagen del cerco de Fray Luis en su Oda IV "Canción al nacimiento de la hija del Marqués de Alcañices", "el terreno cerco" (v. 42), que designa el ámbito de la vida del hombre, sería interiorizada por Quevedo desde la angustia y el advertimiento: «Doy cercos a la negra sepultura ${ }^{23}$. El estado advertido es como el estar alerta del cazador de Ortega y Gasset ${ }^{24}$ ante la presa, pero en el que paradójicamente el ser cazado, la presa (de la muerte), es el hombre.

$\mathrm{La}$ canción «iOh tú que, inadvertido, peregrinas...!» ${ }^{25}$, por ejemplo, se construye sobre la comparación entre un pasado divertido en la corte y la advertencia presente. La senda de los sabios y el saber estoico de la muerte conducen «al escarmiento» como única perspectiva moral y metafísica válida. Así en el salmo XXVII del Heráclito Cristiano, «Bien te veo correr, tiempo ligero» ${ }^{26}$, el penitente arrepentido confiesa: «Yo, dormido, en mis daños persevero.... ${ }^{27}$. O tras Tomás de Kempis: «Acuérdate siempre del fin, y que el tiempo perdido jamás torna ${ }^{28}$ el verso, tan de Quevedo: «El tiempo, que ni vuelve ni tropieza.... ${ }^{29}$. Mientras el hombre divertido se disuelve en el «sueño / de bienes de la tierra» ${ }^{30}$, el hombre advertido «a más honroso / sueño entregó los ojos, no la mente» ${ }^{31}$.

${ }^{22}$ F. de Quevedo (1993), p. 277.

${ }^{23}$ F. de Quevedo (1990), 139, v. 32.

${ }^{24}$ El capítulo primero del ensayo de Ortega «Sobre la caza» (prólogo a Veinte años de caza mayor, del conde de Yebes) lleva por título «El problema de la diversión»; contrasta allí Ortega la dedicación, vida entregada deliberada y responsablemente a una actividad, en este caso la caza, a la diversión, forma de entretenimiento exenta de riesgo y penalidades

${ }^{25} \mathrm{~F}$. de Quevedo (1990), 12.

${ }^{26}$ F. de Quevedo (1990), 39.

${ }^{27}$ F. de Quevedo (1990), v. 5.

${ }^{28}$ Kempis, Imitación de Cristo, Primer tratado (1989), p. 89.

${ }^{29}$ F. de Quevedo (1990), 4, v. 5.

${ }^{30}$ F. de Quevedo (1990), 12, vv. 24-25.

${ }^{31}$ F. de Quevedo (1990), 146, vv. 56-57. 


\section{La antropología de la diversión: correlaciones entre la poesía amorosa, religiosa y moral}

La condición deshabitada y divertida tiene además un previo trasfondo antropológico. El cuerpo deshabitado es resultado de un alma divertida, aunque para Quevedo "una alma divertida» es una contradicción. Por ejemplo, el Dómine Cabra, el avariento maestro segoviano de El Buscón, era espantajo descoyuntado, guiñol, un cuerpo sin alma. Así los hombres divertidos: cuerpos deshabitados, mecanizados, almas ausentes, poseídas por esta forma degenerada de ocio que es la diversión. No son personas, sino tipos sociales desalmados: taberneros, sastres, cornudos, alguaciles, pasteleros, etc.

En las musas Polimnia y Urania el sujeto prescribe descansar en una conciencia serena de la muerte, pero el intento estoico de domesticar el miedo a la muerte a través del raciocinio fracasa: allí donde no alcanza el estoicismo, comienza la poesía moral que don José Manuel Blecua en su clásica edición denominó «metafísica». Estos poemas morales «metafísicos» representan el conflicto entre dos disposiciones vitales: entre el anhelo de alcanzar un paraíso de inconsciencia divertida (juegos, negocios, placeres), y el deber de vivir ante la realidad moral de la muerte. Los poemas se debaten entre el olvido y el sueño de una parte $\mathrm{y}$, de otra, el tormento presente, insomne y lúcido de la "sobreconciencia" advertida.

Tras Séneca, interroga el viejo venerable del sueño "El mundo por de dentro" al joven distraído por los placeres y deleites: “ ¿Tú por ventura sabes lo que vale un día? ¿Entiendes de cuánto precio es una hora? ¿Has examinado el valor del tiempo?"32 En lugar de vivir «divertido» en el tiempo, vivir advertido significa saberse tiempo, percibirse muriendo en el presente, contar y dar valor a las horas desde una consciencia moral. Intelectual y moralmente indigno, el hombre «divertido» huye en vano de la realidad de la muerte. Sólo el sabio advertido logra asumir una consciencia trágica de su vida, como en el soneto «¿Qué otra cosa es verdad sino pobreza? ${ }^{33}$. Por el contrario, en el hombre divertido anidan los siete pecados capitales, como la soberbia", "un cielo mentido / a las inadvertencias del sentido» ${ }^{34}$. Y en la poesía amorosa los elementos del mundo físico reflejan esta naturaleza o propensión humana a la inadvertencia metafísica y moral; por ejemplo, los sonetos "iQué perezosos pies, qué entretenidos...!"35, o "Torcido, desigual, blando y sonoro" ${ }^{36}$, integrados por las correspondencias entre la naturaleza de un arroyo "en las lisonjas divertido", y el corazón del amante "alegre, inadvertido y confiado".

\footnotetext{
${ }^{32}$ F. de Quevedo (1993), p. 277.

${ }^{33}$ F. de Quevedo (1990), 4.

${ }^{34}$ F. de Quevedo (1990), 135, vv. 15-16.

${ }^{35} \mathrm{~F}$. de Quevedo (1990), 475.

${ }^{36}$ F. de Quevedo (1990), 296.
} 
Dentro de la cosmología de la filosofía tomista de la naturaleza y del sistema de imágenes del Renacimiento que Quevedo acoge y reformula, los elementos de la naturaleza asumen propiedades metafísicas reveladoras: desde la presunción como forma de inadvertencia en la letrilla «Rosal, menos presunción» ${ }^{37}$, al elogio del hielo invernal, como emblema de muerte y símbolo de verdad y descanso, en la silva «A una fuente» ${ }^{38}$. El hielo trasciende el psicologismo petrarquista (desamor, indiferencia) para contraponerse con intención metafísica a la alegre fugacidad del río. En la silva amorosa y funeraria "Yace pintado amante»" ${ }^{39}$, alegoría del amor loco y de la brevedad de la vida, deshecha en presentes sucesiones de «yacimientos», Ícaro, símbolo de ambición e inadvertimiento «... con dudoso y divertido vuelo / las lumbres quiso amartelar del cielo» ${ }^{40}$.

También en la poesía satírico-burlesca, el advertimiento se opone a la diversión en la deconstrucción estética de códigos (cortés, neoplatónico) y mitos paganos y «divertidos». Por ejemplo, en el mundo al revés mitológico en La hora de todos o en los conocidos sonetos «Hero y Leandro en paños menores» ${ }^{41} \mathrm{o}$ «Bermejazo platero de las cumbres» ${ }^{42}$.

En su Teología platónica evoca Marsilio Ficino la figura del hombre como la de un exiliado (exul) del mundo, subyugado por un estado continuo de entorpecimiento o tristeza (o maeror); al no poder vivir solo, busca la compañía de los demás, procurando olvidar su inquietud con vanas diversiones (oblectamenta). A través de las diversiones elude el hombre la melancolía para abismarse en una especie de delirio que da a su vida la apariencia de irrealidad de un sueño ${ }^{43}$. Para Quevedo, sabio es quien prescinde de divertidas apariencias y logra una conciencia trágica, advertida y "despierta" de la propia vida. Y mientras para el necio el ocio degenera en diversión, el hombre advertido vela y mira de frente a la muerte.

Los poemas del insomnio amoroso se contraponen al advertimiento y al velar de la fe de la poesía religioso moral. Pero los motivos se entretejen: en la poesía amorosa el motivo del velar involuntario se funde con la llamada a permanecer vigilante, en la orientación moral y escatológica del Evangelio, y en un sentido sentimental e intelectual; el insomnio amoroso converge con el advertimiento moral-cristiano-platónico; los hablantes de la poesía moral condenan el abandono (divertido) al sueño, físico o mental, mientras la poesía amorosa aproxima contenido moral y erótico en la consciencia de unos amantes que se debaten entre

\footnotetext{
${ }^{37}$ F. de Quevedo (1990), 207.

${ }^{38}$ F. de Quevedo (1990), 203.

${ }^{39}$ F. de Quevedo (1990), 200.

${ }^{40} \mathrm{~F}$. de Quevedo (1990), vv. 11-12.

${ }^{41}$ F. de Quevedo (1990), 771.

${ }^{42}$ F. de Quevedo (1990), 536.

${ }^{43}$ M. Ficino (1559), p. 239-241.
} 
el divertimiento/pasión y el advertimiento/desengaño: insomnes penitentes o amantes desdeñados que en la angustia del velar acceden a la visión advertida: «Torcido, desigual, blando y sonoro» ${ }^{44}$; «Al oro de tu frente unos claveles» ${ }^{45}$; «¿Qué perezosos pies, qué entretenidos...»" ${ }^{46}$, etc. Confluyen así poesía moral y poesía amorosa en la voz de un sujeto ingenuo e inconsciente cuyos sentidos y potencias se hallan sumidos en el sueño, en la inadvertencia ante una muerte que cree lejana. El amante desengañado del Heráclito es prójimo del amante rechazado de la musa del amor profano Erato, y puede leerse, dentro de una diacronía sentimental y biográfica, como presagio del advertimiento intelectual del sabio estoico de la poesía moral, o del advertimiento espiritual del penitente en la poesía religiosa.

\section{Advertimiento y metafísica de la guerra}

También el rey se debe a una política y razón de estado advertidas: no debe "descuydarse" con sus ministros, no debe dar pábulo a la "voz de la adulación", sino que debe imitar a Cristo quien "en lugar de echarse a dormir... velaba la noche de la cena" ${ }^{47}$, según manda la Política de Dios. Y así:

Reynar es velar [...] Rey que duerme, gouierna, entre sueños; y quando mejor le va, sueña que gouierna. De modorras y letargos de Príncipes adormecidos adolecieron muchas Repúblicas y Monarquías: ni basta al Rey tener los ojos abiertos, para entender que està despierto, que el mal dormir es con los ojos abiertos. Y si luego los allegados velan con los ojos cerrados, la noche y la confusión serán dueños de todo, y no llegarà a tiempo alguna aduertencia ${ }^{48}$.

O en el Marco Bruto, acerca de la muerte de César, símbolo de muerte por inadvertencia:

Pondera Suetonio que cuando cayó, por caer decente se cubrió con la propia toga los pies. Advertencia para caer bien y para morir a escuras, no es advertencia del juicio, sino circunstancia del yerro (...) Cuidar de menudencias para después de muerto, y no de los riesgos para no morir, quiere ser piedad, y no sabe; quiere parecer advertencia, y no puede: pretendió ser recato honesto, y quedose en melindre castigado, ${ }^{, 49}$.

\footnotetext{
${ }^{44}$ F. de Quevedo (1990), 296.

${ }^{45}$ F. de Quevedo (1990), 339.

${ }^{46}$ F. de Quevedo (1990), 475.

${ }^{47} \mathrm{~F}$ de Quevedo (1966), p. 79.

${ }^{48}$ F. de Quevedo (1966), p. 80.

${ }^{49}$ F. de Quevedo (1992), p. 960.
} 
La epístola moral horaciana «No he de callar, por más que con el dedo»; eleva la Edad Media y la Reconquista a modelos del vivir advertido: «Del tiempo el ocio torpe, y los engaños / del paso de las horas y del día, / reputaban los nuestros por extraños $\rangle^{50}$. Mientras el vivir divertido equivale a evasión del mundo, sueño de la muerte y divagación, el militar advertido «a más honroso / sueño entregó los ojos, no la mente»" ${ }^{51}$. Por ello en el Sueño del infierno "muchos capitanes, maestres del campo, generales y ejércitos" van "por el camino de la mano derecha" ${ }^{152}$. Tras la primera de las epístolas de Séneca a Lucilio, donde sólo el tiempo es nuestro ${ }^{53}$, el hombre advertido se sabe tiempo y por ello no es arrastrado ni menguado por «los engaños / del paso de las horas y del día» ${ }^{54}$, como los cortesanos «sin decoro» de la hora presente. Y recordemos que el tratado Providencia de Dios concluido en la prisión de San Marco se cierra con un elogio de la guerra.

Con razón indicaba Christopher Maurer que el contenido ideológico de la epístola a Olivares es «el recelo del ocio» ${ }^{55}$ inscrito en «la teoría circular» de Quevedo que, tras los historiadores y satíricos romanos, propone un nexo causal entre paz, abundancia, ocio y vicio. Pero ocio no como otium, ligado a la skolé del libro primero de la Metafísica de Aristóteles, un estado de contemplación y recogimiento en calma transparente, sino como su degeneración: hebescere otio u otio diffluere, ociosidad, «tiempo no logrado, la vida no interiorizada ${ }^{56}$, «el ocio torpe» ${ }^{57}$, el «ocio bestial con nombre de Paz santa» ${ }^{58}$. Quevedo enfrenta «la militar valiente disciplina» ${ }^{59}$ a la divertida ociosidad, al «vicioso» nec otium del «áspero dinero ${ }^{60}$, del placer y las distracciones: cañas, toros, fiestas palaciegas, vestidos, perfumes, etc., modos del vivir divertido, sumidos en el sueño de las apariencias y lo accidental, conducentes al abandono de las obligaciones religioso-militares, de la lucha sagrada por el ideal de la Reconquista. Contra el olvido divertido, propugna Quevedo la gratitud y memoria ancestral; contra el negocio, la ascesis guerrera.

La decadencia amenaza a Castilla como producto del tránsito del laborioso vivir advertido al improductivo esparcimiento divertido, en una nueva correspondencia, esta vez entre la moral individual privada y la moral colectiva y

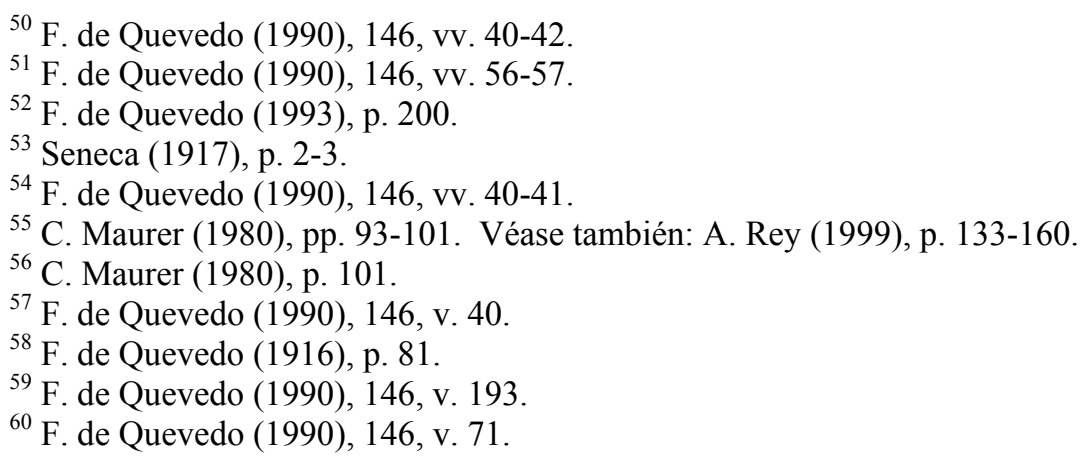


política de la nación. De ahí el apóstrofe a España en el título de un soneto: «Advertencia a España de que ansí como se ha hecho señora de muchos, así será de tantos enemigos envidiada y perseguida y necesita de continua prevención por esta causa» ${ }^{61}$. Y de ahí la petición en 1625 a don Gaspar de Guzmán: «Pasadnos vos de juegos a trofeos» ${ }^{62}$. Es decir, "pasadnos" de la diversión a la guerra, estado del advertimiento constante en correlación con un mítico Estado aristocráticosagrado, restaurado y regenerado, integrado por heroicos guerreros -no hay heroísmo sin advertimiento. Los "juegos" testimonian la caída de una monarquía frívola a manos de una oligarquía secularizada de comerciantes. En lugar de Guerra Santa, sólo habría, deplora Quevedo, guerra de intereses. En el Sueño de la muerte y en La hora de todos desacredita la búsqueda de la paz por el CondeDuque de Olivares y el proyecto de paz universal del papa Urbano VIII, mientras se alababa la guerra. En su retorno a los clásicos y el espíritu de Cruzada, la "Epístola satírica y censoria" anticipa a Hegel, para quien la guerra preserva la salud moral de los pueblos: así como el movimiento del océano impide la corrupción que sería el resultado de una perpetua calma, también así, mediante la guerra, el pueblo escapa de la corrupción que resultaría de una paz perpetua ${ }^{63}$. Y, en su vínculo entre libertad y guerra ("Y aquella libertad esclarecida, que en donde supo hallar honrada muerte, nunca quiso tener más larga vida" ${ }^{, 4}$ ) al Nietzsche de El ocaso de los ídolos: "La guerra educa para la libertad. Pues iqué es la libertad? Tener voluntad de autorresponsabilidad. Volverse indiferente a la fatiga, a la dureza, a la privación, incluso a la vida... El hombre que ha llegado a ser libre, y mucho más el espíritu que ha llegado a ser libre, pisotea la despreciable especie de bienestar con que sueñan los tenderos... El hombre libre es un guerrero" 65 . Y Zarathustra predicaba también como el autor de "El escarmiento" el domino propio, la aceptación del destino, el Amor Fati, la sumisión a la verdad, y la purificación a través del combate y del dolor.

\section{La ética del advertimiento puro}

Al denunciar la frivolidad de las diversiones de la aristocracia palaciega, «el grave eclesiástico» del Quijote (II, 32) describía la vida moral del hombre como una realidad unívoca, resuelta, conclusa. Su admonición se enderezaba a unos duques devotos del placer que bajo disfraz de fiesta y homenaje escarnecían y se burlaban de don Quijote. Como galeotes condenados a diversión perpetua, los duques experimentaban la vida como un juego de niños, un pasatiempo por el que no hay que pagar precio alguno. Pero su antagonista, el «grave eclesiástico» era

\footnotetext{
${ }^{61}$ F. de Quevedo (1990), 71.

${ }^{62}$ F. de Quevedo (1990), 146, v 166.

${ }^{63}$ G. W. F. Hegel (1881), p. 210.

${ }^{64}$ F. de Quevedo (1990), (146, vs 31-33), p. 40.

${ }^{65}$ F. Nietzsche (2009), p. 135-136.
} 
presentado también por Cervantes como una figura antipática por ejercer su puritano y excesivo advertimiento constante -más allá de la vida. El grave eclesiástico opera como juez, que interpreta la vida moral como realidad cerrada, vista para sentencia. El punto de vista de Cervantes, de equilibrio y dinamismo cognoscitivo entre el prodesse et delectare, se diferencia igualmente del puritano confesor palaciego como de los duques.

Tras Cervantes, Ortega ironizó en La idea de principio en Leibniz la aspiración a una ética del advertimiento puro ${ }^{66}$. La patética seriedad, el absolutismo del intelecto que atribuye a Heidegger y a Sartre en el capítulo "El lado jovial de la filosofía" es contrario, piensa, a la realidad de la vida, que consiste en la unidad radical y antagónica de deporte y angustia, desesperación y fiesta, muerte y resurrección continua. Por ello el temple de la filosofía debe, según Ortega, ser también jovial y risueño, como el deporte y el juego. Para el Quevedo grave, fiesta y juego son frivolidad y falsedad. Y afín a Quevedo es la denuncia que hace Heidegger como «inautenticidad» no sólo de las diversiones tranquilizadoras, sino también de la obtusa indiferencia ante la muerte. La disposición advertida de Quevedo se diferencia así tanto del modo vital integrador cervantino, que aúna el prodesse et delectare del novelista, como de la antropología de la razón vital orteguiana; en lugar de velar vanamente la muerte con «necias diversiones», el hombre advertido mira de frente al «negro cerco» ${ }^{67}$ con una suerte de serena lucidez angustiada. La atonía ante la hora última y toda forma de distracción hedonista repugnan al Quevedo moral. Hay una escisión radical, casi inhumana, entre la actitud vital «grave» y otra propia de «chisgarabises», alejada del humor cervantino, o del auto sacramental de Calderón, que (re)liga inmanencia y trascendencia, reconciliando juego y sabiduría ${ }^{68}$.

\section{El homo ludens ante la poética del advertimiento}

Y sin embargo, la diversión como una faceta de la necesidad humana de jugar se manifiesta en la obra festiva del autor de El Buscón. El cultivo intermitente pero fiel que a lo largo de su asendereada trayectoria le brindó Quevedo a la musa satírica y burlesca le da la razón a Ortega y Gasset cuando, en Idea del teatro (1946), afirma: "El hombre necesita descansar de su vida y para ello ponerse en contacto, volverse a o verterse en una ultravida. Esta vuelta o versión de nuestro ser hacia lo ultravital e irreal es la diversión. La distracción, la diversión es algo consustancial a la vida humana...Y no puede sorprendernos que el más grande creador y disciplinador de cultura que jamás ha existido, Platón ateniense, hacia el fin de sus días se entretenga haciendo juegos de palabras con el vocablo griego

\footnotetext{
${ }^{66}$ J. Ortega y Gasset (1958), pp. 151, 165-183.

${ }^{67}$ F. de Quevedo (1990), 28, v. 10.

${ }^{68}$ Para el concepto de "religación": X. Zubiri (1993), p. 178.
} 
que significa $\pi \alpha 1 \delta \varepsilon i^{\prime} \alpha$ (paideía) y el que significa juego, broma, farsa (paidiá), y nos diga, en irónica exageración, ni más ni menos, que la vida humana es $\pi \alpha 1 \delta \imath^{\prime} \alpha$ juego y, literalmente, añada que eso que tiene de juego es lo mejor que tiene." (Leyes 803, 4) ${ }^{69}$. Quevedo es eminentemente Homo ludens, título del ensayo de Johan Huizinga sobre las raíces lúdicas de los actos culturales (mitología, arte, filosofía), y el papel civilizador y educativo del juego, sustituto de la violencia a través del lenguaje y de la poesía ${ }^{70}$. El juego, pensaba Huizinga, puede elevarse hasta las cumbres de la belleza y de la santidad, donde deja atrás a lo serio. Tras Friedrich Schiller y Eugenio D'Ors el hombre no se define solo en su doble dimensión de homo sapiens y de homo faber sino como el hombre entretenido y distraído. Siguiendo a Gracián, D'Ors creía que el ser del hombre responde a una antropología de la razón como poiesis, es decir como actividad creadora. El homo ludens dorsiano es el contemplador y gozador de formas y figuras, como el de Gracián era un descifrador de enigmas. En sentido estricto, el discurso del advertimiento de Quevedo es incompatible con el Quevedo lúdico y profano de la musa satírico-burlesca: no armoniza, a diferencia de Cervantes, los principios agónicos y lúdicos de la existencia, advertimiento y diversión. No puede decirse que para Quevedo haya -como en cambio sí lo había para Gracián, Nietzsche y Ortega- isomorfismo entre juego y vida moral. Quevedo recorre ambas disposiciones vitales separadamente, desde el «ayuntamiento» o acercamiento lúdico y sacrílego entre carnaval y devoción, en tantos pasajes memorables de $E l$ Buscón y Los Sueños, hasta la perspectiva moral rigorista de los tratados ascéticos. Pero en realidad, y por eso la poesía satírica no es sólo chanza, sí existen correspondencias: Quevedo percibe lo ridículo de las personas como una variante de la falta de advertimiento: los sujetos satíricos son risibles por esa misma falta de advertimiento. Aunque en su madurez el Quevedo grave reconociera formalmente en los «juguetes» satírico-burlescos pasados (y presentes) sólo vanidad y divertimento, la causticidad del juicio moral latente brotaba de la mirada advertida. Por ello, si Los sueños enfrentan dos mundos (sueño y realidad, diversión y mundo «por de dentro», mundo vislumbrado como verdad), el ingenio satírico-burlesco, contra la poesía amorosa y su representación neoplatónica de la mujer como breve mundo, es también inseparable de una antropología metafísica dualista y de una epistemología advertida, que reconoce en el mundo físico una realidad caída, degradada, risible. Y, sobre todo, existe correspondencia entre el Quevedo satírico-divertido y el moral-advertido en su concepción de la lengua. Rechazan ambos, como fruto de la pereza, las frases hechas, los clichés, las muletillas: formas expletivas de indigencia mental y moral. El programa

${ }^{69}$ J. Ortega y Gasset (1977; primera edición, 1958), p. 55-56.

${ }^{70}$ F. Schiller (1990), J. Huizinga (1955), Eugenio d'Ors (1914). 
lingüístico del autor de las Genealogía de los modorros y de las Premáticas como crítica del lugar común y de los hábitos mentales dormidos, "divertidos", propios de los malos poetas, es, en el fondo, una poética del advertimiento. Sin advertimiento no es posible la virtud moral, pero tampoco una estética conceptista de la agudeza.

\section{La tradición del advertimiento, entre Platón, Pascal y Ortega}

Quevedo asumió la división social tradicional entre mentalidad plebeya y noble (entre el polités y el meteco, patricios y plebeyos, nobles y villanos, hidalgos y pecheros) para fundirla a una variante de la fenomenología del vivir advertido que, desde Sócrates, Séneca, Ficino, Gracián a Heidegger y el existencialismo, recorre el pensamiento occidental. Primero Sócrates había sido condenado a muerte por «corromper», es decir, desvelar las conciencias de los atenienses («partero de espíritus» le llamó Platón en el Teeteto): despertar como revelación de una condena universal a muerte, aquélla que como humanos los atenienses desearían olvidar «jugando», como los hombres divertidos, a seguir siendo niños. Los negocios serían modos de «hacer como si no pasara nada», de jugar a que no pasa nada. La filosofía socrática es una suerte de práctica o ejercicio vital consistente en abandonar los juegos y pasatiempos infantiles, y aprender a pensar contra la muerte. El hombre libre, el ciudadano no puede vivir sin este «saber» de la muerte.

Y poco después de Quevedo, Pascal llamaría divertissement a lo que distrae del deber humano de reflexión: espectáculos, juegos, negocios, la búsqueda de prestigio y de aplauso. Y aunque la crítica a la Escolástica por Pascal está ausente en Quevedo, su consideración sobre la miseria humana, también desde una interpretación rigorista de la moral cristiana, es muy próxima. Según Pascal sólo le divertissement consuela al hombre en sus miserias, pero, a la vez que distraen, las diversiones acercan al hombre a la muerte, constituyéndose paradójicamente en la mayor de sus miserias. Sin la diversión el hombre se hunde en el ennui, pero ese ennui le lleva a buscar un antídoto más poderoso: la diversión aparta al hombre de sí para que llegue sin sentirlo al final del camino, y oculta así la visión del precipicio: el ser humano corre sin miedo hacia el fin después de haberse puesto delante de los ojos algo que le impedía divisarlo. La vida humana, mientras más pletórica en lo material, más vacía: el juego, la caza, las visitas, los espectáculos, la falsa perpetuación del propio nombre, son para Pascal divertidas variaciones de la vanitas barroca.

Los mil fragmentos de Pascal puedan acaso leerse, en su brevedad aforística, 
como la filosófica prolongación de la poesía moral de Quevedo ${ }^{71}$. Y, sin embargo, mientras el nombre de Pascal surge inevitable vinculado al penetrante análisis del papel que juegan las diversiones en la vida del hombre no se hallan, en el relato «oficial» del devenir de la conciencia intelectual europea, textos de Quevedo. No solo la filosofía de Séneca y de San Agustín ${ }^{72}$ : también los pensamientos de Pascal hallan su analogía lírica en la poesía moral y metafísica de Quevedo. Por ejemplo, los sonetos "Huye sin percibirse el día" o "Vivir es caminar breve jornada»" donde navega el hombre divertido hasta arribar insensiblemente a orillas de la muerte. Quevedo lo expresó así en la aforística prosa de El sueño del infierno:

En el camino de la vida... el partir es el nacer, el vivir el caminar, la venta el mundo, y en saliendo de ella es una jornada breve a la pena o a la gloria. ${ }^{74}$

La vida del hombre es para Quevedo encrucijada, bivium (Sueño del infierno ${ }^{75}$ ), y el camino a seguir, como en Proverbios XXXIV de Antonio Machado: «¿Cuál fue, Jesús, tu palabra? / ¿Amor? ¿Perdón? ¿Caridad? / Todas tus palabras fueron / una palabra: Velad» ${ }^{76}$.

En suma, Quevedo examinó avant la lettre el divertissement de Pascal dentro de una prolongada meditatio mortis, que asume la forma de una condena de la vida divertida como indiferencia y atonía ante la muerte y distracción hedonista ${ }^{77}$. Pero mientras que Pascal no tuvo relaciones cortesanas difíciles, el autor del Marco Bruto y La hora de todos inscribe su poesía de vanidades amorosa y moral en un marco de rivalidad y frustración erótica, y en tensión (moral) con la diversión (social). El temple del hombre advertido ante la muerte semeja el perpetuo estado avizor de un cortesano ante sus rivales. O el estar en alerta del cazador ante su presa descrito en el citado ensayo de Ortega sobre la caza. Podría decirse que el hombre advertido de Quevedo es un cazador metafísico que se sabe inexorablemente destinado a ser cazado por la muerte.

El «ensimismamiento» orteguiano se opone a la «alteración» como el

\footnotetext{
${ }^{71}$ La diversión que oculta el paso fugaz de las horas es el motivo de los pensamientos 1, 74, $109,131,137,139,142,143,164,166,167,170,171,324,421,462,465,628,710$. Pascal (1976).

${ }^{72}$ Ver: H. Sánchez Martínez de Pinillos (1991).

${ }^{73}$ F. de Quevedo (1990), 11.

${ }^{74}$ F. De Quevedo (1993), p. 195. Gracián reelaboró en El Criticón la misma idea “... que lo que la naturaleza va hilando de la vida, el cielo lo va desvanando, y quitándonos los días con sus vueltas; y cuando los mortales andan más diligentes y más solícitos, saltando y brincando, entonces se van más deshaziendo”. B. Gracián (1996), p. 762.

${ }^{75}$ F. De Quevedo (1993), p. 277.

${ }^{76}$ A. Machado (1940), p. 159.

${ }^{77}$ Para una fenomenología del «talante» jansenista como religiosidad del rigorismo moral: J. L. López Aranguren (1952), p. 166-183.
} 
«advertimiento» quevediano a la «diversión» ${ }^{78}$. Lo que para Ortega diferencia al hombre del animal es su poder de ensimismamiento. Perdido entre las cosas, náufrago en el mundo, el hombre mediante un enérgico esfuerzo puede retirarse a su intimidad, para así poder formarse ideas sobre su circunstancia y su posible dominación; es el ensimismamiento, la vita contemplativa de los romanos, el theoretikós bios, de los griegos, la theoría; después puede el hombre volver a sumergirse en el mundo, para actuar en él conforme a un plan preconcebido; es la acción, la vita activa, la praxis. Pero la vida debe tener sentido, interviniendo aquí el pensamiento al servicio del mundo interior. El hombre existe en el mundo natural, pero éste le es extraño a su "parte extra-natural" por lo que el hombre ha de transformar la naturaleza para construirse un mundo. El "ensimismamiento" consiste en memoria y continuidad, y cuando el hombre se di-vierte, y en la medida en que lo hace y se distrae, pierde sus lazos con la tradición, "se discontinúa" de sí propio y deja transitoriamente de ser hombre, renuncia a ser sí mismo y se vuelve otro -alter-, alterado, divertido. La única vía ascendente es entonces el ensimismamiento, la entrada en sí, la interiorización del pasado y la confrontación advertida del porvenir. Y como el hombre divertido es antecesor del "señorito satisfecho"79, es el héroe y "hombre auténtico" de Ortega (y de Heidegger y de Sartre) sucesor del hombre advertido de Quevedo.

\section{Diversión y posmodernidad}

La dimensión reaccionaria de la obra de Quevedo combate, desde el providencialismo y una metafísica del honor y de la guerra, la modernidad emergente. Y así el maquiavelismo, el pragmatismo económico de "la secta de los dineristas", y el pacifismo de Urbano VIII son condenados en La hora de todos desde una deontología imposible del advertimiento guerrero y metafísico constante. Y los poemas morales y de amor expresan la discontinuidad biográfica y metafísica entre un pasado (divertido) de amantes, cortesanos, pretendientes, etc., y un presente (advertido) de desengaño, «senda» que conduce a «El escarmiento» ${ }^{80}$ como despertar y conversión. Advertido se enfrenta a divertido como la realidad al sueño, dentro de las oposiciones binarias privilegiadas en el Barroco: ilusión y desengaño, realidad y apariencia, pasión y razón, fortuna y Providencia. Ante la disposición moral, advertida, el mundo se manifiesta «por de dentro», como verdad; entonces, el sujeto caído, agitado y distraído por negocios, sumido en la cueva platónica, puede volver en sí, despertar y ver más allá de las sombras de la caverna. Esta dualidad platónico-agustiniana es para Quevedo también ética e histórica: contra la presente decadencia hedonista, un pasado idealizado de

\footnotetext{
${ }^{78}$ Ensimismamiento y alteración. Meditación de la técnica. (1939).

${ }^{79}$ J. Ortega y Gasset (1930).

${ }^{80}$ F. de Quevedo (1990), 12.
} 
guerreros medievales cristianos. Advertimiento equivale a interioridad y nobleza, a valor, disciplina y jerarquía.

En cierto modo, Quevedo prefigura a Nietzsche al desenmascarar la falsa nobleza social como una forma de inadvertencia: la religión del plebeyo es superstición o fariseísmo en Los sueños; la presunción verbal, divertida inconsciencia plebeya en las "Premáticas del desengaño contra los poetas güeros" o "La culta latiniparla"; el ideal del bien público será desvelado como pasión de mando en Olivares, expresión de una voluntad de poder llevada a la tiranía; el ideal burgués del mercantilismo es culto sacrílego del oro, etc. En el pensamiento español del siglo XX, divertimiento plebeyo y advertimiento noble revivirán en la dicotomía de Ortega y Gasset entre el hombre noble, autoexigente, ascético y fiel a sí propio, y los hombres-masa, niños mimados del período de entreguerras. Y un académico de la lengua española afirmaba con ironía, hace una década, "haber descubierto el vocablo de nuestro tiempo: es este primaveral adjetivo que ahora se está adhiriendo a los más insólitos compañeros. Hay colores divertidos, relojes, corbatas, pisos, broches, pantalones...: todo, absolutamente todo puede ser divertido." ${ }^{" 81}$ Asimismo, los tipos quevedescos urbanos de la poesía satíricoburlesca y la prosa festiva, de El Buscón y Los Sueños carecen de personalidad, serían "hombres masa": hablan y existen como niños divertidos, vegetando, deshabitados. En cambio, el sabio estoico, el penitente agustiniano, el hombre advertido de Quevedo y el héroe orteguiano se forman transformándose, haciéndose personas contra sí mismos, contra el niño que fueron por medio del ensimismamiento/advertimiento, desprendidos de la inmediatez y del deseo del mundo, revelado ya "por de dentro". Así como en el drama barroco La vida es sueño Segismundo -"el hombre-fiera"- se elevaba a "príncipe" en el acto de vencerse a sí propio, o en la novela alegórica El Criticón de Gracián la conciencia se desdoblaba en el camino de la vida entre el maduro y advertido Critilo y el ingenuo divertido Andrenio, del "hombre viejo" nace, emerge agónicamente de los despojos del caducado homúnculo divertido, el hombre advertido de Quevedo.

Diversión hedonista y advertimiento ascético son respuestas a la angustia por el paso del tiempo histórico: declinar del Imperio católico español, alta nobleza parasitaria, divertidas simulaciones en el gran teatro del mundo barroco, o en la actualidad, colapso económico y vaciamiento cultural en el Occidente del "Matrix" financiero y mediático. La diversión, en tanto instante fugaz y huida virtual hacia el no-ser de los placeres, entra en la lógica del desarrollo posmoderno previo a la "crisis" del 2008: rechazo de la noción de deuda, exigencia de crédito ilimitado, soberanía del capricho y amputación del sentido de lo sacro que, según Quevedo, arruinan no solo la conciencia moral sino los fundamentos de la conciencia metafísica. El advertimiento, en cambio, abre una vía de inmersión en

81 “Divertido” en F. Lázaro Carreter (1997), p. 482-485: 482. 
la trascendencia presente de la tradición: liberación, profundización interior y elevación a través de la meditación ascética, la lectura o la guerra. Mientras la diversión encarna una fuga hacia lo inconsciente y banal, hacia la "utopía del fun", el advertimiento posee vocación supraconsciente y metafísica.

La disolución del mundo tradicional añorado por Quevedo se consuma en las sociedades de la vigilancia y el espectáculo del fin de la modernidad: sociedad "neo-barroca" que participa también, en forma secularizada, de algunos de los rasgos que J. A, Maravall asignase a la cultura barroca: dirigida, urbana y de masas, poseída por un horror vacui informativo, saturada de imágenes y de propaganda ${ }^{82}$. Aparece así una versión nueva del cortesano deshabitado y divertido del siglo XVII, engranaje fundamental también de las estructuras de poder del postcapitalismo industrial: el hombre "light", "en serie", tipo del individuo desarraigado, desacralizado y abierto ("open-minded"), consumidor insaciable de objetos y de noticias manipuladas pero vacío de tradición y forma interior, hombre producto, mecanizado en el sentido de de Le rire de Bergson, y que reconocemos en El Buscón. También Neil Postman en su crítica del consumismo tecnológico posmoderno asociaba, como Quevedo, diversión y muerte: Amusing Ourselves to Death ${ }^{83}$ Sucesor de los "chisgaravises" ${ }^{\text {" }}$ satirizados en Los sueños y moralizados por Gracián como seres impersonales incapaces de "dar razón de sí" "195 la distraída y cosificadora mirada -poseída por el "pensamiento único" del sistema- del consumidor contribuyente posmoderno, estandarizado, tecnoformo, lobotomizado y espiado, carente de sensibilidad metafísica no es ya capaz de memoria histórica ni de rebelión política. En este sentido no puede decirse que diversión y advertimiento no sean también hoy conceptos operativos, vivos.

\section{Obras citadas}

BERGSON, Henri: Le rire. Essai sur la signification du comique, París, Éditions Alcan, 2000 (1924).

Cervantes, Miguel de: El Quijote, ed. de Martín de Riquer, Barcelona, Juventud, 1950.

D'ORS, Eugenio, La filosofia del hombre que trabaja y la filosofia del hombre que juega, (1914), Madrid, Libertarias/Prodhufi, 1995.

FICINO, Marsilio: Theologia platonica. De innmortalitate animorum, XIV, 7, París, 1559.

GraCiÁn, Baltasar: El Criticón, ed. Santos Alonso, Madrid, Cátedra, 1996.

- Agudeza y arte de ingenio, ed Emilio Blanco, Madrid, Cátedra, 1998.

\footnotetext{
${ }^{82}$ J. A Maravall (1975).

${ }^{83}$ N. Postman (1985). Sobre la interrelación de diversión y muerte en la poesía de Quevedo: H. Sánchez M. De Pinillos (1991).

${ }^{84}$ F. De Quevedo (1993), p. 363.

${ }^{85}$ B. Gracián (1996), p. 299-300.
} 
Hegel, G. W. F.: Discursos sobre la Filosofia de la Historia, tr. J. Sibree, Londres, Goerge Bell \& Sons, 1881.

HUIZINGA, Johan: A Study of the Play-Element in Culture, Boston, Beacon Press, 1955.

KeMPIS, Tomás de: Imitación de Cristo, trad. Fray Luis de Granada, Madrid, Aguilar, 1989.

LaÍn EnTRAlgo, Pedro, Ocio y trabajo, Madrid, Revista de Occidente, 1960.

LÁzARo CARRETER, Fernando, El dardo en la palabra, Barcelona, Galaxia Gutenberg-Círculo de lectores, 1997.

LÓPEZ ARANGUREN, José Luis: Catolicismo y protestantismo como formas de existencia, Madrid, Revista de Occidente, 1952.Madrid, Biblioteca Nueva, 1998.

LuIS DE LeÓn, Fray: Poesías, ed. P. Ángel C. Vega, Madrid, Saeta, 1955.

MACHAdO, Antonio: Poesías completas, México, Espasa-Calpe, 1940.

MARAVAll, José Antonio, La cultura del Barroco, Madrid, Ariel, 1975 (Revisada, 1980).

MAURER, Christopher: "Interpretación de la Epistola satírica y censoria de Quevedo», en Cuadernos Hispanoamericanos, 361-362, (1980), pp. 93-101.

METGE, Bernat, Lo somni, ed. Martín de Riquer, Barcelona, Planeta, 1985.

NIETZCHE, Friedrich, El ocaso de los ídolos, Ed., trad, pról. Roberto Echevarren, 2009.

ORTEGA Y GASSET, José, La rebelión de las masas, Madrid, Revista de Occidente, 1930.

—Ensimismamiento y alteración. Meditación de la técnica, Madrid, Espasa-Calpe, 1939.

- "Sobre la caza", prólogo a Veinte años de caza mayor del conde de Yebes, Madrid, Espasa-Calpe, 1943.

- La idea de principio en Leibniz y la evolución de la teoría deductiva, Buenos Aires, Biblioteca de la Revista de Occidente, Emecé Editores, 1958.

-Ideas del teatro, Madrid, Revista de Occidente, 1977 (Primera edición: 1958).

PASCAL, Blaise: Pensées, intr. Dominique Descostes, París, Garnier-Flammarion, 1976.

PIEPER, Josef: Leisure. The Basis of Culture, intr. T. S. Eliot, Nueva York, Pantheon Books, 1952.

Platón: Teeteto, o de la ciencia, Trad J. A. Miguez, Madrid, Buenos Aires, México,Aguilar, 1960.

Postman, Neil, Amusing Ourselves to Death; Public Discourse in the Age of Show Business, Nueva York, Penguin, 1985.

QUEVEDO, Francisco de: España defendida, ed. Selden Rose, Madrid, Boletín de la Real Academia de la Historia, T. 69, 1916.

- Politica de Dios, Gobierno de Cristo. ed. James O. Crosby, Madrid, Castalia,1966.

- Poesía original completa, ed. José Manuel Blecua, Barcelona, Planeta, 1990. 
- Obras completas. Prosa, 2 vols. Estudio preliminar, edición y notas Felicidad Buendía, Madrid, Aguilar, 1992 (sexta reimpresión).

- Poesía moral (Polimnia), ed. A. Rey. Madrid y London, Támesis, 1992b.

- Sueños y discursos, Ed., introd. y notas James O. Crosby, Madrid, Clásicos Castalia, 1993.

REY, Alfonso: «Concepto de nobleza y visión de la guerra en la obra de Quevedo», en Rostros y máscara: Personajes y temas de Quevedo, Pamplona, EUNSA, 1999, pp. 133-160.

SÁNCHEZ M. DE PINILlos, Hernán: «Intensidad de doctrina y sentimiento en el tiempo en un poema moral de Quevedo», en Romanische Forschungen, 103/4, (1991), pp. 402-424.

- "El salmo XVI de Heráclito Cristiano de Quevedo: una lectura interpretativa e intertextual del soneto". Studi Ispanici, 3: 19-48, 1991/1993.

- "Un nuevo estado de conciencia: la interioridad vacía en el soneto "Ah de la vida' de Quevedo.” Revista de Estudios Hispánicos 24 (1997): 37-55.

- «Elementos sagrados y profanos en la poesía de Quevedo», en La Perinola. Revista de Investigación Quevediana, 9, (2005), pp. 183-213.

SÉNECA, Lucius Annaeus: IV Epistulae Morales I. Books I-LXV. Tad. Richard M. Gummere en Moral Essays in Three Volumes, Cambridge, Londres, Harvard UP, 1917.

SCHILLER, Friedrich, Kallias : cartas sobre la educación estética del hombre, trad. de J. Feijoo y J. Seca Gil, Rubí, Anthropos, Editorial del hombre, 1990.

VALERY, Paul: Le Cimetière Marin, Ed. y trad. Graham Dunstan Martin, Austin, University of Texas Press, 1971.

VIVES, Juan Luis: Obras completas, tomo Segundo, ed. y trad. Lorenzo Riber, Madrid, Aguilar, 1947.

YNDURÁIN, Francisco: «Sobre el pensamiento de Quevedo», en Relección de clásicos, Madrid, Prensa Española, 1969, pp. 171-214.

ZUBIRI, Xavier: El problema filosófico de las religiones, Madrid, Alianza Editorial, 1993. 